\title{
Relation of protein synthesis and amino acid oxidation: effects of protein deprivation
}

\author{
V. V. A. M. Schreurs, G. Mensink, H. A. Boekholt and R. E. Koopmanschap \\ (Department of Animal Physiology, Agricultural University, Haarweg 10, 6709 PJ \\ Wageningen, Netherlands)
}

Received 20 March 1985; accepted 22 July 1985

\begin{abstract}
Adaptation to protein deprivation was studied in male rats during three weeks. A control group (normal diet) was compared with an experimental group (equicaloric protein-free diet) for: body weight, tissue weights, amino acid oxidation and incorporation of ${ }^{14} \mathrm{C}$-tyrosine in total tissue protein and in individual muscle proteins. Amino acid oxidation was used as a tool for estimating whole body protein synthesis. The deprived rats adapted their metabolism by restricting amino acid oxidation and slowing down protein synthesis. Amino acid oxidation continues by an uneven loss of proteins from the tissues. In muscle the composition and the relative synthesis rate of constituent proteins were not affected. An integrated and quantitative approach of the changes in protein metabolism is discussed. Compared to other organs liver and kidney tend to maintain a relative high rate of protein turnover.
\end{abstract}

Key-words: nutrition, protein deprivation, amino acid oxidation, protein synthesis, protein turnover.

Introduction. In the steady state, the synthesis of proteins mainly contributes to the protein turnover, a physiological need for the maintenance of the body. Since amino acids, essential for protein synthesis, are also subjected to other metabolic processes a continuous supply of exogenous amino acids (protein) is required. This daily uptake normally equals amino acid oxidation. After application of a radiolabelled amino acid the expired ${ }^{14} \mathrm{CO}_{2}$ indicates which fraction of the total amino acid flux is subjected to oxidation. The complementary part of the flux is used for protein synthesis. Therefore daily protein synthesis can be calculated from the level of amino acid oxidation and daily protein intake. Upon protein deprivation the body develops a strategy to survive. Amino acids required for continuation of protein turnover are mobilized by breakdown of tissue proteins. The pattern of protein loss by the tissues is, however, very complicated and changes in time (Garlick et al., 1975). This pilot study describes a quantitative integration of different phenomena in protein deprivation.

Materials and methods. Measurements were made on 10 male rats ( 3 months, $\cong 300 \mathrm{~g}$ ) divided in a control (normal diet) and an experimemental (equicaloric protein-free diet) group. Both groups had free access to feed and water. Both diets contained: $10 \%$ sucrose, $7 \%$ soya bean oil, $3 \%$ cellulose and $2 \%$ Gistocal, a 
commercial additive containing vitamins and minerals. In addition the normal diet contained $58 \%$ maize starch and $20 \%$ soya protein. The protein-free diet was supplemented with $75 \%$ maize starch and $3 \%$ sucrose. Body weights were followed during three weeks. At four intermediate points of time tissue weights were examined for one animal of each group. After three weeks the fifth animal in each group received in one hour an intravenous infusion of $3 \mathrm{ml}$ saline containing $50 \mu \mathrm{Ci} \mathrm{L}-[\mathrm{U}$ ${ }^{14} \mathrm{C}$ ltyrosine. The expired ${ }^{14} \mathrm{CO}_{2}$ was trapped in a solution of potassium hydroxide. After four hours the animal was killed and tissues were weighed and sampled. The specific activity (SA) of total tissue protein and individual muscle proteins was examined in protein fractions obtained by SDS gel filtration (Schreurs et al., 1983, 1985).

Results. The animals on a normal diet kept growing ( $1 \mathrm{~g}$ per day). Protein-deprived rats continuously lost body weight ( $2 \mathrm{~g}$ per day). After three weeks their weight was $85 \%$ of their starting weight and $77 \%$ of the control value. The changes in body weight were the apparent result of changing tissue weights and most closely parallel skeletal muscle (hind limb). Relatively, the weight loss of spleen, kidney and liver was higher, whereas that of testis, brain and heart was lower than the weight loss of the whole body. Initially (after 2 days), the weight loss of liver was most pronounced.

Analysis of the expired air for ${ }^{14} \mathrm{CO}_{2}$ indicates that, during protein deprivation, only 3 instead of $15 \%$ of the infused radioactivity was expired.

The incorporation of ${ }^{14} \mathrm{C}$-tyrosine, expressed as the specific activity (SA; $\mathrm{dpm}^{1} / \mu \mathrm{g}$ protein), was used for the comparison of the synthesis rate of tissue proteins (Table 1). Both groups showed a considerable (10-20-fold) difference in SA of the various tissue proteins. Upon a protein-free diet the values for all tissues were lower than on the control diet. In most cases this amounted to 50-60\%, except for liver and kidney which were only $80 \%$ of their control value.

The further analysis of muscle tissue indicates that, at least from $\mathrm{m}$. soleus and $\mathrm{m}$. longissimus, protein deprivation does not affect the composition and the relative synthesis rate of the individual proteins.

Table 1 . Specific activity of tissue protein ( $\mathrm{dpm}^{1 / \mu \mathrm{g}}$ protein).

\begin{tabular}{llll}
\hline Tissue & $\begin{array}{l}\text { Normal } \\
\operatorname{diet}(\mathrm{A})\end{array}$ & $\begin{array}{l}\text { Protein-free } \\
\operatorname{diet}(\mathrm{B})\end{array}$ & $\begin{array}{l}\text { Ratio } \\
\mathrm{B} / \mathrm{A}(\%)\end{array}$ \\
Liver & 3.94 & 3.27 & 83 \\
Kidney & 5.07 & 3.77 & 74 \\
& & & \\
Brain & 1.44 & 0.86 & 60 \\
Heart & 1.56 & 0.84 & 54 \\
Diaphragm & 0.77 & 0.42 & 55 \\
M. longissimus & 0.31 & 0.18 & 58 \\
\hline
\end{tabular}

${ }^{1} \mathrm{dpm}=$ disintegrations per minute. The SI unit is $\mathrm{Bq}$ (becquerel). $1 \mathrm{dpm} \cong 16.667 \mathrm{mBq}$. 
Discussion. The continuation of body processes requires the supply of (exogenous) amino acids (protein), the fate of which is normally oxidation. Upon protein deprivation the body is forced to adapt metabolism in order to survive. All our data confirm an amino acid sparing action in response to protein deprivation. The amount of amino acid oxidation can be estimated from the experimental data. For the control rats we measured a daily food intake of $19.3 \mathrm{~g}$, corresponding with $3500 \mathrm{mg}$ protein. The growth rate $(1 \mathrm{~g}$ per day) indicates a maximal retention of $180 \mathrm{mg}$ protein in the tissues $(18 \%$ protein). Therefore daily about $3400 \mathrm{mg}(3320-3500 \mathrm{mg})$ amino acids will be oxidized. The deprived rats lose body weight ( $2 \mathrm{~g}$ per day) mainly due to the loss of tissue proteins. Therefore the loss of body weight corresponds to a mobilization of $360 \mathrm{mg}$ amino acids for oxidation. This is approximately $10 \%$ of the oxidation level in the control rats.

Our ${ }^{14} \mathrm{CO}_{2}$ experiments indicate that the amino acid oxidation of $3400 \mathrm{mg}$ and $360 \mathrm{mg}$ correspond to $15 \%$ and $3 \%$ of the amino acid flux in the normal and deprived rats, respectively. The complement of the flux for oxidation is the flux for protein synthesis. Total protein synthesis per day can be calculated for the normal $(58 / 15 \times 3400 \mathrm{mg}=19270 \mathrm{mg})$ and the deprived $(97 / 3 \times 360 \mathrm{mg}=11640 \mathrm{mg})$ rats, indicating a reduction to $60 \%$. This calculated reduction is in good agreement with the data of Table 1, except for liver and kidney. The relatively high values for the latter organs indicate a preference for maintaining a high protein turnover suggesting that a further lowering of their turnover rate would interfere with a proper functioning.

The data indicate that even in protein deprivation the nett protein degradation (= amino acid oxidation) is only a small fraction of the total protein degradation which mainly contributes to the turnover of proteins.

Studies on muscle proteins indicate that protein loss is not attended with a change in the composition of the muscle nor with a change in the relative synthesis rate of individual tissue proteins.

So, protein deprivation leads to a general but uneven decrease of the turnover of tissue proteins. As a consequence the waste of amino acids is reduced. Long-term effects of lowered turnover rates are unknown. Amino acid oxidation levels can be helpful in estimating changes of protein metabolism.

The quantitative description will be more precise when the loss of protein is accurately determined by a study of the nitrogen balance.

\section{References}

Garlick, P. J., D. J. Millward, W. P. T. James \& J. C. Waterlow, 1985. The effect of protein deprivation and starvation on the rate of protein synthesis in tissues of the rat. Biophysica et Biochimica Acta 414: 71-84.

Schreurs, V. V. A. M., H. A. Boekholt \& R. E. Koopmanschap, 1983. Gel filtration in sodium dodecyl sulphate of hydrophobic muscle proteins on Sephacryl S-400 superfine. Journal of Chromatography 254: 203-210.

Schreurs, V. V. A. M., H. A. Boekholt, R. E. Koopmanschap \& W. van Rotterdam, 1985. Relative synthesis rate of individual muscle proteins: a new approach. Netherlands Journal of Agricultural Science 33: $287-292$. 
This synopsis is based on a report entitled 'De invloed van eiwitvrije voeding op de turnover van weefseleiwitten bij de rat' by Gert Mensink, Department of Animal Physiology, Agricultural University, Wageningen, 1984. 62 pp., 16 figs., 8 tables, 14 refs., 4 appendices. Dutch.

Available as paper copy (order R044P, $f 20$ including postage) or microfiche (order R044M, f 12.50 including postage) at: NARD, clo Pudoc, P.O. Box 4, 6700 AA Wageningen, Netherlands (telex 45015 blhwg $\mathrm{hl}$ ). 